\title{
Pengelolaan dan Dinamika Sampah di Desa Ulekan Kabupaten Karawang Di Tinjau Dari Peraturan Daerah Kabupaten Karawang Nomor 9 Tahun 2017 Tentang Pengelolaan Sampah
}

\author{
Reonaldy Saputra Hutagalung ${ }^{1^{*}}$, Oci Senjaya $^{2^{*}}$ \\ Fakultas Hukum Universitas Singaperbangsa Karawang \\ J1. HS Ronggo Waluyo Kecamatan Telukjambe Timur Kabupaten Karawang \\ *Correspondence email : reonaldy99@gmail.com
}

\begin{abstract}
Abstrak. Permasalahan Sampah di Indonesia akan bertambah karena ketidaksadaran Masyarakat akan permasalahan sampah yang serius. Permasalahan pengelolaan sampah menjadi isu yang harus kita selesaikan secara bersama-sama agar tumbuh rasa cinta dan kepedulian terhadap lingkungan yang bersih dan sehat. Metode penelitian yang kami gunakan yaitu metode empiris dengan langsung mengunjungi Dinas Lingkungan Hidup Karawang, dengan mewawancarai langsung kepala bagian UPTD 1 DLHK (Dinas Lingkungan Hidup Karawang) yaitu pak Luki, menanyakan tentang pemberian solusi dan gerakan pemerintah sendiri terhadap permasalahan proses pengelolaan sampah di Desa Ulekan demi mewujudkan kualitas lingkungan yang sehat dan bersih. Mengacu pada pengertian sampah dan jenis-jenisnya, diperlukan penanganan dan pengelolaan sampah dengan cara yang baik. Merujuk informasi dari Departemen Pekerjaan Umum kota Semarang (2008), penanganan sampah dapat dilakukan dengan pengelolaan sampah 3R yaitu : Reuse (Menggunakan Kembali), Reduce (Mengurangi), Recycle (Daur Ulang). Mengingat pertumbuhan penduduk yang semakin meningkat setiap harinya, maka sampah yang dihasilkan setiap warga akan semakin meningkat dan membuat permasalahan mengenai sampah yang menumpuk dan berserakan. Hal ini diperburuk dengan kurang memadainya tempat dan lokasi pembuangan sampah, masih kurangnya pemahaman masyarakat tentang manfaat sampah, Berbagai hal tersebut menyebabkan menurunnya kualitas lingkungan yang berdampak negatif bagi masyarakat.
\end{abstract}

Kata kunci : Pengelolaan, Sampah, Peraturan, Daerah.

\begin{abstract}
Waste problems in Indonesia will increase due to public awareness of serious waste problems. The problem of waste management is an issue that we must solve together in order to grow a sense of love and concern for a clean and healthy environment. The research method that we use is the empirical method by directly visiting the Karawang Environmental Office, by directly interviewing the head of the UPTD 1 DLHK (Karawang Environmental Service) namely Mr. Luki, asking about providing solutions and the government's own movement to the problem of the waste management process in Ulekan Village. in order to create a quality environment that is healthy and clean. Referring to the definition of waste and its types, it is necessary to handle and manage waste in a good way. Referring to information from the Department of Public Works of Semarang City (2008), waste management can be done with $3 R$ waste management, namely: Reuse (Reuse), Reduce (Reduce), Recycle (Recycle). Given the increasing population growth every day, the waste produced by each citizen will increase and create problems regarding waste that accumulates and is scattered. This is exacerbated by inadequate places and locations for waste disposal, there is still a lack of public understanding of the benefits of waste. Various things have led to a decline in environmental quality which has a negative impact on the community.
\end{abstract}

Keywords: Management, Waste, Regulation, Region.

\section{PENDAHULUAN}

Sampah merupakan sebuah material sisa yang dibuang sebagai hasil dari proses produksi, baik itu industri maupun rumah tangga. Definisi lain dari sampah adalah sesuatu yang tidak diinginkan oleh manusia setelah proses/penggunaannya berakhir. Adapun material sisa yang dimaksud adalah sesuatu yang berasal dari manusia, hewan, ataupun dari tumbuhan yang sudah tidak terpakai. Wujud dari sampah tersebut bisa dalam bentuk padat, cair ataupun gas.

1. Jenis-Jenis Sampah

Setelah memahami pengertian sampah, kita juga perlu mengetahui jenis-jenisnya. Beberapa jenis sampah dapat diklasifikasikan dalam beberapa kelompok. Berikut ini adalah jenis-jenis sampah:

a. Jenis Sampah Berdasarkan Sumbernya

1) Sampah yang berasal dari manusia

2) Sampah dari alam

3) Sampah konsumsi

4) Sampah nuklir/limbah radioaktif

5) Sampah industri

6) Sampah pertambangan

b. Jenis Sampah Berdasarkan Sifatnya 
1) Sampah Organik (Degradable). Pengertian sampah organik adalah sampah yang dapat membusuk dan terurai sehingga bisa diolah menjadi kompos. Misalnya, sisa makanan, daun kering, sayuran, dan lain-lain.

2) Sampah Anorganik (Undegradable). Pengertian sampah anorganik adalah sampah yang sulit membusuk dan tidak dapat terurai. Namun, sampah anorganik dapat didaur ulang menjadi sesuatu yang baru dan bermanfaat. Misalnya botol plastik, kertas bekas, karton, kaleng bekas, dan lain-lain.

c. Jenis Sampah Berdasarkan Bentuknya

Berdasarkan bentuknya, sampah dapat dibagi menjadi beberapa kelompok, diantaranya :

1) Sampah padat merupakan, Sampah pada merupakan material yang dibuang oleh manusia (kecuali kotoran manusia). Jenis sampah ini diantaranya plastik bekas, pecahan gelas, kaleng bekas, sampah dapur, dan lainlain.

2) Sampah Cair merupakan, Sampah cair merupakan bahan cair yang tidak dibutuhkan dan dibuang ke tempat sampah. Misalnya, sampah cair dari toilet, sampai cair dari dapur dan tempat cucian.

2. Cara Pengelolaan Sampah

Mengacu pada pengertian sampah dan jenis-jenisnya, diperlukan penanganan dan pengelolaan sampah dengan cara yang baik. Merujuk informasi dari Departemen Pekerjaan Umum kota Semarang (2008), penanganan sampah dapat dilakukan dengan pengelolaan sampah 3R. Berikut penjelasan pengelolaan sampah 3R tersebut:

a. Reuse (Menggunakan Kembali): Merupakan metode penanganan sampah dengan cara menggunakan kembali sampah tersebut secara langsung, baik untuk fungsi yang sama atau fungsi lain.

b. Reduce (Mengurangi): Merupakan metode pengelolaan sampah dengan cara mengurangi segalah hal yang dapat menyebabkan timbulnya sampah.

c. Recycle (Daur Ulang): Merupakan metode pengelolaan sampah dengan cara mendaur ulang sampah menjadi sesuatu yang baru dan dapat digunakan. ${ }^{1}$

3. Dampak Sampah Pada Masyarakat

Pada umumnya sampah memberikan dampak buruk bagi masyarakat. Menurut Gelbert (1996), ada tiga dampak sampah terhadap manusia dan lingkungannya:

a. Dampak Sampah Terhadap Kesehatan

Penanganan sampah yang tidak baik akan memberikan dampak buruk bagi kesehatan masyarakat di sekitarnya. Sampah tersebut akan berpotensi menimbulkan bahaya bagi kesehatan, seperti:

1) Penyakit diare, tifus, kolera

2) Penyakit jamur

3) Penyakit cacingan

b. Dampak Sampah Terhadap Lingkungan

Selain berdampak buruk terhadap kesehatan manusia, penanganan sampah yang tidak baik juga mengakibatkan dampak buruk bagi lingkungan. Seringkali sampah yang menumpuk di saluran air mengakibatkan aliran air menjadi tidak lancar dan berpotensi mengakibatkan banjir. Selain itu, sampah cair yang berada di sekitar saluran air akan menimbulkan bau tak sedap.

c. Dampak Sampah Terhadap Sosial dan Ekonomi

Penanganan sampah yang tidak baik juga berdampak pada keadaan sosial dan ekonomi. Beberapa diantaranya adalah :

1) Meningkatnya biaya kesehatan karena timbulnya penyakit

2) Kondisi lingkungan tidak bersih akibat penanganan sampah yang tidak baik, hal ini pada akhirnya akan berdampak pada kehidupan sosial masyarakat secara keseluruhan.

Ketika jumlah manusia terbatas dan hidup secara sederhana, pada umumnya cara hidup dan bermukim manusia masih serasi dengan lingkungan alam sehingga pada tingkat seperti ini masalah lingkungan belum dikenal orang, akan tetapi, setelah jumlah manusia bertambah banyak, serta ilmu pengetahuan yang dimiliki manusia terus berkembang, pola tingkah lakunya pun berubah pula, antara lain, dengan mengadakan perubahan pada lingkungan menurut keinginannya, perubahan yang pada mulanya kecil, berubah dengan cepat seiring dengan pertumbuhan penduduk, serta perkembangan ilmu dan teknologinya yang begitu pesat, pada akhirnya segala kegiatan tersebut mengganggu keserasian manusia dengan lingkungan. ${ }^{2}$

Dahulu kala, orang-orang hidup tanpa stres atas pengaruh atau risiko yang mengganggu melalui kontaminasi udara, kontaminasi air, atau kontaminasi ekologis yang menjadi masalah sekarang, karena orang menerima dan percaya pada kapasitas kerangka normal untuk beradaptasi secara normal (kerangka pendukung kehidupan). Memang

${ }^{1}$ https://www.maxmanroe.com/vid/umum/pengertian-sampah.html, Diakses Tanggal 18 November 2019.

${ }^{2}$ Prof. Dr. M. Daud Silalahi, S.H., Pengaturan Hukum Sumber Daya Air dan Pengelolaan Lingkungan Hidup di Indonesia, P.T. Alumni, Bandung, 2008, hlm 2-3 
bahkan di fase awal industrialisasi, ketika puncak asap mulai mencemari udara, air kotor air limbah (sungai dan lautan) dan sampah diturunkan di tanah yang subur, orang masih percaya pada kemampuan udara untuk membersihkan sendiri, air (sungai dan laut) dapat mengencerkan benda-benda asing itu secara alamiah tanpa perlu khawatir akan bahayanya. Meskipun terdapat pengaturan hukum terhadap masalah gangguan pada kesehatan pada revolusi industri, misalnya pada zaman Raja Henry Vll pada abad ke-18, umumnya kekhawatiran itu masih dalam taraf keyakinan bahwa alam mempunyai keterbatasan daya serap dan proses alam sendiri mampu mengolah setiap benda asing yang dibuang ke lingkungan (alam). Demikian pula halnya dengan manusia yang hidup di planet bumi, mereka mempunyai daya penyesuaian diri atas perubahan-perubahan yang terjadi pada lingkungan pada setiap waktu, tempat, dan keadaan tertentu secara evolusi atas dasar terapan ilmu dan teknologi ciptaannya sendiri. Penyesuaian diri manusia terhadap perubahan-perubahan alam sekitarnya terlihat, antara lain melalui proses budaya yang lama, misalnya kemampuan manusia dalam menciptakan teknologi untuk melindungi dirinya dari pengaruh alam yang buruk. $^{3}$

\section{METODE}

Lokasi Penelitian dilakukan di DLHK (Dinas Lingkungan Hidup Karawang). Karena peneliti melihat adanya permasalahan mengenai pengelolaan sampah dan penumpukan sampah dengan skala yang sedang, dekat dengan pemukiman Masyarakat dan jalan yang dilalui warga sehingga mempengaruhi kualitas hidup sehat masyarakat dan mengganggu aktivitas warga.

Dalam hal penelitian ini, yang digunakan lebih mengacu pada jenis penelitian yang dilihat dari segi tujuannya yaitu jenis penelitian studi kasus Karena menurut peneliti ini melibatkan dimana adanya permasalahan yang sangat kompleks dan perlu adanya solusi serta kesadaran masyarakat di lingkungan itu sendiri.

Pendekatan, dalam pendekatan ini peneliti menggunakan pendekatan Empiris karena data-data yang didapat berdasarkan apa yang di dapat di dinas lingkungan hidup secara langsung. Di mana dalam penelitian ini selain data diperoleh dari beberapa informan data juga bisa diperoleh melalui kajian pustaka atau buku buku yang dianggap berkaitan dengan penelitian ini.

\section{HASIL DAN PEMBAHASAN}

\section{Penyebab sampah berserakan di sepanjang Desa Ulekan}

Saat ini sampah menjadi permasalahan yang kian mendesak di Indonesia. Mengingat pertumbuhan penduduk yang semakin meningkat setiap harinya, maka sampah yang dihasilkan setiap warga akan semakin meningkat dan membuat permasalahan mengenai sampah yang menumpuk dan berserakan. Hal ini diperparah dengan minimnya tempat dan area pembuangan sampah, kurangnya pemahaman masyarakat tentang manfaat sampah, dan keengganan daerah untuk memanfaatkan kembali sampah, karena mengingat sampah dipandang sebagai sesuatu yang berantakan dan harus dibuang. dibuang karena rasa gengsi. Hal-hal yang berbeda ini menyebabkan penurunan sifat iklim yang berdampak buruk pada daerah setempat. Jika mendengar istilah sampah yang terlintas dalam benak kita adalah setumpuk limbah yang menimbulkan aroma berbau busuk yang sangat menyengat. Sampah diartikan sebagai sesuatu barang atau sisa-sisa makanan yang sudah tidak dipakai lagi oleh manusia, atau sudah tidak digunakan lagi dalam suatu kegiatan. Sampah dapat membawa dampak yang buruk pada kondisi kesehatan manusia. Bila sampah dibuang secara sembarangan atau ditumpuk tanpa ada pengelolaan yang baik, maka akan menimbulkan berbagai dampak, baik untuk kesehatan maupun lingkungan. Tumpukan sampah yang serius terhadap lingkungan dapat menyebabkan timbulnya berbagai penyakit. Sampah yang tidak dikelola dengan baik dan benar akan menimbulkan dampak bagi masyarakat sekitar. Pengelolaan sampah adalah pengumpulan, pengangkutan, pemrosesan dan daur ulang, atau pembuangan dari material sampah. Pengelolaan sampah harus dilakukan berdasarkan yang diatur dalam Peraturan Daerah Karawang, baik terhadap pemerintah maupun warga sekitar, guna menciptakan lingkungan yang bersih dan sehat. ${ }^{4}$

"Sampah adalah masalah bersama bukan hanya masalah Pemerintah saja dan seharusnya masyarakat juga sadar akan menjaga lingkungan di sekitarnya dan memperbaiki pola dari masyarakat sendiri" imbuh pak lucky sebagai dinas lingkungan hidup Karawang. Pemerintah sudah berkali-kali melakukan pembersihan di sekitar desa Ulekan tersebut, tetapi tetap saja masyarakat tidak kunjung sadar akan permasalahan sampah yang ada, seharusnya masyarakat juga ikut ambil bagian di sana, karena peran Pemerintah atau Dinas lingkungan tidak full di sana saja, Dinas lingkungan hidup sudah melakukan pembersihan berkali-kali dan bahkan memasang Spanduk atau himbauan dan ajakan untuk

${ }^{3}$ Prof. Dr. M. Daud Silalahi, S.H., Hukum Lingkungan Dalam Sistem Penegakan Hukum Lingkungan Indonesia, P.T. Alumni, Bandung, 2001, hlm 6-7

${ }^{4}$ Chika Asyifa Riansyah dan Rezy Januar Wilyana. "Peran Masyarakat Dan Pemerintah Dalam Proses Pengelolaan Sampah Di Desa Cibungur Indah RT. 002 RW. 014 Dikaitkan Dengan Peraturan Daerah Kabupaten Karawang Nomor 9 Tahun 2017 Tentang Pengelolaan Sampah”. Jurnal Hukum Lingkungan. Oktober 2018. 
Reonaldy Saputra Hutagalung dan Oci Senjaya, Pengelolaan dan Dinamika Sampah di Desa Ulekan Kabupaten Karawang Di Tinjau Dari Peraturan Daerah Kabupaten Karawang Nomor 9 Tahun 2017 Tentang Pengelolaan Sampah

menyadarkan masyarakat akan Kebersihan lingkungan dan tidak lama spanduk itu hilang entah kemana dan masyarakat tidak kunjung sadar akan membuang sampah dengan baik. Seharusnya masyarakat juga mempunyai terobosan-terobosan dalam mengatasi permasalahan sampah yang ada, dan karena yang membuang sampah di sana bukan hanya masyarakat sekitar lingkungan tersebut tetapi masyarakat luar dari desa tersebut juga membuang sampah disitu, dan menyebabkan sampah melebihi daya tampung TPS (Tempat Pembuangan Sementara). ${ }^{5}$

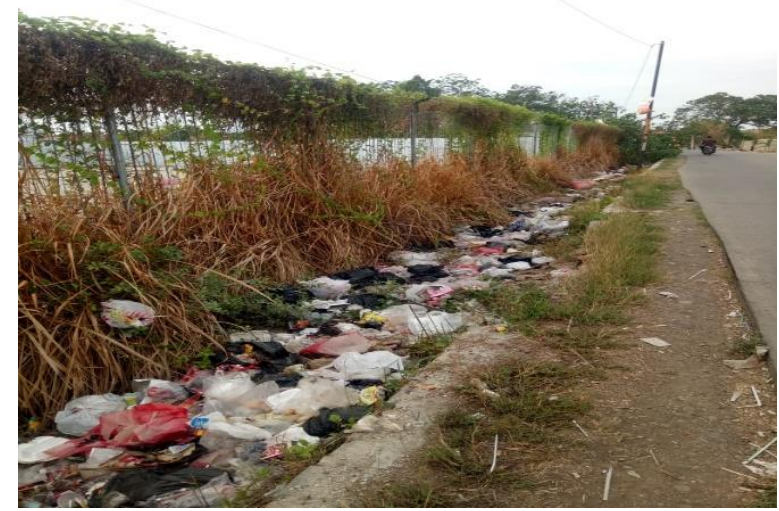

Gambar 1.2 Sampah yang berserakan di sepanjang jalan Desa Ulekan yang dekat dengan TPS

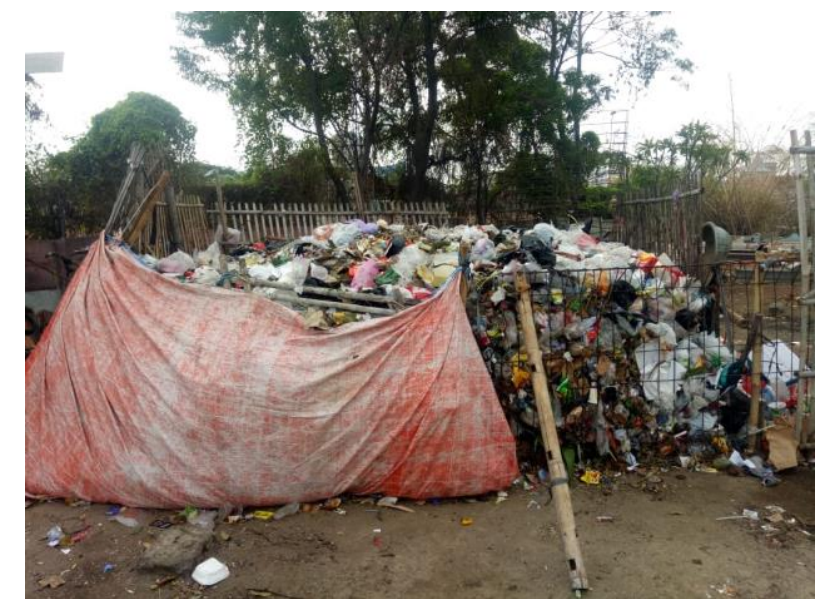

Gambar 1.3 TPS (Tempat Pembuangan Sementara) di Desa Ulekan

Dampak yang diberikan oleh dinas lingkungan hidup terhadap pengelolaan sampah di Desa Ulekan dirasa masih belum maksimal, karena masyarakat juga masih kurang kesadaran akan dampak dari membuang sampah sembarangan itu sendiri, yang dimana masih banyak masyarakat membuang sampah di sepanjang jalan-jalan yang ada di Desa Ulekan tersebut, bahkan pengendara motor dan mobil yang lewat juga masih saja membuang sampah sembarangan di sekitar jalan desa ulekan tersebut sehingga membuat sampah bertambah banyak dan berserakan di jalan sekitarannya, bahkan sampai-sampai menimbulkan bau yang tidak sedap, yang dapat mengganggu warga sekitar dan pengguna jalan, dan menjadikan pemandangan di sekitarnya menjadi kurang bagus. Seharusnya masyarakat dapat membantu Pemerintah dalam menangani kasus sampah yang ada disana, sehingga dapat sama-sama ambil bagian dalam menangani sampah yang berserakan disepanjang jalan di Desa Ulekan ini, seperti Rt dan Rw setempat mengadakan ajakan ke masyarakat di Desa tersebut untuk sama-sama bergotong royong untuk membersihkan sampah di sepanjang jalan Desa Ulekan dan setelah di bersihkan sehabis itu membuat kesepakatan antar masyarakat melalui musyawarah untuk menerapkan sanksi tegas kepada pembuang sampah sembarangan di Desa Ulekan tersebut.

\section{Penerapan Pengelolaan dan Dinamika Sampah di Desa Ulekan Kabupaten Karawang di Tinjau Dari Peraturan Daerah Kabupaten Karawang Nomor 9 Tahun 2017 Tentang Pengelolaan Sampah .}

Tugas dan wewenang pemerintah menurut Peraturan Daerah Kabupaten Karawang Nomor 9 Tahun 2017 Tentang Pengelolaan Sampah. Tercantum didalam Pasal 5 dan Pasal 6 yang berbunyi:

\footnotetext{
${ }^{5}$ Wawancara bersama bapak lucki Kepala bagian UPTD 1 Dinas Lingkungan Hidup Karawang (DLHK)
} 
Reonaldy Saputra Hutagalung dan Oci Senjaya, Pengelolaan dan Dinamika Sampah di Desa Ulekan Kabupaten Karawang Di Tinjau Dari Peraturan Daerah Kabupaten Karawang Nomor 9 Tahun 2017 Tentang Pengelolaan Sampah

Pemerintah Daerah dalam penyelenggaraan bertugas :

Pasal 5

a. Meningkatkan kesadaran masyarakat hidup bersih dengan Pengelolaan Sampah dengan baik dan benar;

b. Melakukan penelitian, pengembangan teknologi Pengurangan Sampah, dan Penanganan Sampah;

c. Memfasilitasi, mengembangkan dan melaksanakan upaya Pengurangan Sampah, Penanganan Sampah, dan Pemanfaatan Kembali Sampah;

d. Melaksanakan Pengelolaan Sampah dan memfasilitasi penyediaan prasarana dan sarana Pengelolaan Sampah;

e. Mendorong dan memfasilitasi pemanfaatan hasil Pengolahan Sampah;

f. Memfasilitasi penerapan teknologi spesifik lokal yang berkembang pada masyarakat setempat untuk mengurangi dan menangani Sampah; dan

g. Melakukan koordinasi antar Perangkat Daerah dan lembaga pemerintah lainnya di Daerah, masyarakat dan dunia usaha agar terdapat keterpaduan dalam Pengelolaan Sampah.

Pasal 6

(1) Pemerintah Daerah dalam penyelenggaraan Pengelolaan Sampah berwenang:

a. Menetapkan kebijakan dan strategi Pengelolaan Sampah Berdasarkan kebijakan nasional dan provinsi;

b. Menyelenggarakan Pengelolaan Sampah skala Daerah sesuai dengan norma, standar, prosedur dan kriteria yang ditetapkan oleh pemerintah pusat;

c. Melakukan pembinaan dan pengawasan kinerja Pengelola Sampah yang dilaksanakan oleh pihak lain;

d. Menetapkan lokasi TPS, TPST, dan/atau TPA;

e. Melakukan pemantauan dan evaluasi secara berkala setiap 6 (enam) bulan selama 20 (dua puluh) tahun terhadap TPA dengan sistem pembuangan terbuka yang telah ditutup; dan

f. Menyusun dan menyelenggarakan Sistem Tanggap Darurat Pengelolaan Sampah sesuai dengan kewenangannya.

(2) Penetapan lokasi TPST dan TPA sampah sebagaimana dimaksud pada ayat (1) huruf d merupakan bagian dari rencana tata ruang wilayah.

Dalam pengelolaan sampah sendiri Pemerintah Kabupaten Karawang mengaplikasikanya dengan cara sanitary landfill yaitu sistem yang dimana sampah dibuang dan di tumpukan di lokasi yang cekung, memadatkannya dan kemudian menimbunnya dengan tanah. Dan Pemerintah juga membuat Bank sampah yang dimana Bank sampah adalah suatu tempat yang digunakan untuk mengumpulkan sampah yang sudah dipilah-pilih seperti sampah organik dan non organik. Hasil dari pengumpulan sampah yang sudah di pilih-pilih terlebih dahulu akan disetorkan ke tempat pengepul sampah yang dimana sampah tersebut akan diolah kembali untuk kerajinan tangan atau hal yang dapat digunakan kembali. Dan Pemerintah juga mengelola sampah dengan maggot untuk mengatasi sampah organik yang biasanya bila ditumpuk dan dibiarkan akan berbau tidak sedap, maggot sendiri merupakan belatung dari black soldier flys hermetia illucens yang termasuk keluarga lalat, yang dimana maggot ini seperti belatung yang hanya mengkonsumsi sampah organik.

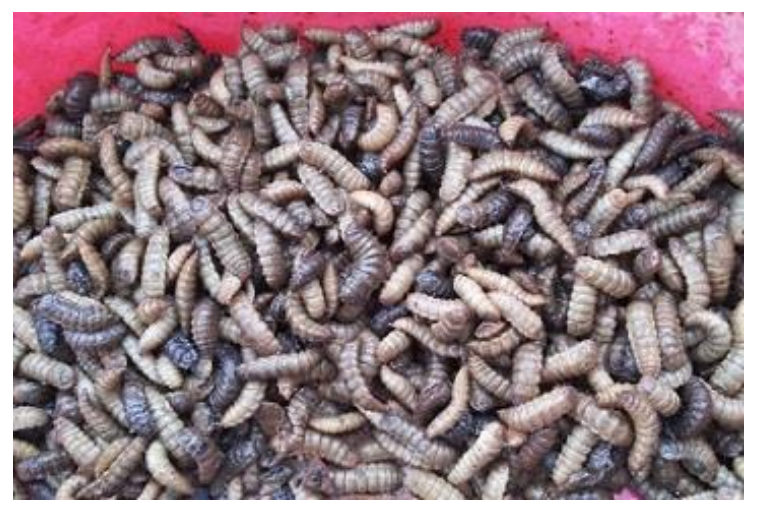

Gambar 1.1 Gambar Maggot Pemakan Sampah. ${ }^{6}$

Dan pemerintah sendiri sebenarnya mempunyai inovasi mengikuti budaya luar Negeri yang lebih efektif untuk menerapkan pengelolaan sampah sendiri yaitu seperti TPS Elektronik yang diterapkan di Negara Jepang, tetapi Pemerintah sendiri memikirkan dampak yang timbul karena penerapan sampah elektronik di Indonesia yang dirasa

\footnotetext{
${ }^{6}$ http://intp.fapet.ipb.ac.id/?p=1816, Diakses Tanggal 26 November 2019.
} 
Pemerintah belum siap dengan budaya Indonesia sendiri yang terkadang belum dapat menjaga fasilitas umum, seperti telepon umum pada jamannya yang selalu saja ada orang-orang yang tidak bertanggung jawab merusak fasilitas umum tersebut, dan masyarakat juga tidak mempunyai kesadaran untuk menjaga fasilitas yang telah diberikan Pemerintah, sehingga penerapan TPS elektronik tidak sesuai dengan target yang dibuat oleh Pemerintah melalui Dinas Lingkungan Hidup Kabupaten Karawang dalam mengaplikasikan hal tersebut dan budaya Indonesia sendiri yang belum mampu dalam menjaga fasilitas umum.

Sebenarnya dalam cara agar lingkungan sekitar desa tersebut indah, bersih dan nyaman tanpa adanya sampah yang berserakan yang ada dilingkungan dekat dengan sawah maupun pemukiman masyarakat desa Ulekan Kabupaten Karawang adalah dengan dilakukannya sosialisasi yang dengan cara memberikan pemahaman-pemahaman kepada warga sekitar agar peduli terhadap kebersihan dan kenyamanan lingkungan sekitar. Pemberian pemahaman sekaligus menanyakan tentang kondisi lingkungan di Ulekan Kabupaten Karawang dan juga harus bisa memberikan pemahaman secara langsung kepada masyarakat agar lebih bisa menyikapi sampah dengan bijak, karena setelah apa yang kita lihat bahwa masyarakat sekitar kebanyakan hanya membuang sampah di irigasi sekitaran tempat sampah yang dapat menyebabkan pencemaran di lingkungan sekitar.

Sudah seharusnya masyarakat sekitar mengadakan Kerja Bakti selama setahun sekali selain itu, diadakannya gerobak sampah untuk mengangkut sampah per 3 (tiga) hari atau 1 (satu) minggu. Hal itu dapat disikapi oleh warga sekitar dengan baik dengan sudah dimulainya Kerja Bakti tahunan bersama seluruh masyarakat, dengan memagari wilayah yang dianggap sudah banyak sampah menumpuk dan berserakan, tindakan tersebut dapat membuat kesadaran masyarakat tumbuh bahwa agar wilayah tersebut kembali bersih dan rapih.

\title{
SIMPULAN
}

Dalam pengelolaan sampah sendiri Pemerintah mengaplikasikan dengan cara sanitary landfill yaitu sistem yang dimana sampah dibuang dan di tumpukan di lokasi yang cekung, memadatkannya dan kemudian menimbunnya dengan tanah. Dampak yang ditimbulkan oleh dinas lingkungan hidup dirasa belum maksimal karena masyarakat juga masih kurang kesadaran akan dampak membuang sampah sembarangan, yang dimana masih banyak yang membuang sampah sembarangan, bahkan pengendara motor dan mobil pun terkadang membuang sampahnya sembarangan di sekitar jalan desa ulekan tersebut sehingga membuat sampah bertambah banyak dan berserakan di jalan sekitarnya. "Sampah adalah masalah bersama bukan hanya masalah Pemerintah saja dan seharusnya masyarakat juga sadar akan menjaga lingkungan di sekitarnya dan memperbaiki pola dari masyarakat sendiri" imbuh pak luky sebagai dinas lingkungan hidup. Pemerintah sudah berkali-kali melakukan pembersihan di sekitar desa Ulekan tersebut, tetapi tetap saja masyarakat tidak kunjung sadar akan permasalahan sampah yang ada, seharusnya masyarakat juga ikut ambil bagian di sana, karena peran Pemerintah atau Dinas lingkungan tidak full di sana saja, Dinas lingkungan hidup sudah melakukan pembersihan berkali-kali dan bahkan memasang Spanduk atau himbauan dan ajakan untuk menyadarkan masyarakat akan Kebersihan lingkungan.

\section{DAFTAR PUSTAKA}

\section{Buku}

S.Hadiwiyoto, Penanganan dan Pemanfaatan Sampah, Jakarta: Yayasan Idayu, 1983.

G. Theisen Tchobanoglous, dan S.A. Vigil, Integrated Solid Waste Mangement Engineering Principles and Mangement Issues.

Prof. Dr. M. Daud Silalahi, S.H., Pengaturan Hukum Sumber Daya Air dan Pengelolaan Lingkungan Hidup di Indonesia, P.T. ALUMNI, Bandung, 2008.

Prof. Dr. M. Daud Silalahi, S.H., Hukum Lingkungan Dalam Sistem Penegakan Hukum Lingkungan Indonesia, P.T. ALUMNI, Bandung, 2001.

\section{Peraturan Perundang-Undangan}

Peraturan Daerah Nomor 9 Tahun 2017 Tentang Pengelolaan Sampah.

\section{Naskah Jurnal}

Chika Asyifa Riansyah dan Rezy Januar Wilyana. "Peran Masyarakat Dan Pemerintah Dalam Proses Pengelolaan Sampah Di Desa Cibungur Indah Rt.002 Rw.014 Dikaitkan Dengan Peraturan Daerah Kabupaten Karawang Nomor 9 Tahun 2017 Tentang Pengelolaan Sampah”. Jurnal Hukum Lingkungan. Oktober 2018.

\author{
Naskah Internet \\ https://id.wikipedia.org/wiki/Hukum_lingkungan \\ http://intp.fapet.ipb.ac.id/?p=1816 \\ https://www.maxmanroe.com/vid/umum/pengertian-sampah.html
}

